\title{
Lifestyles and sexuality in men and women: the gender perspective in sexual medicine
}

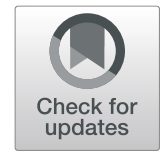

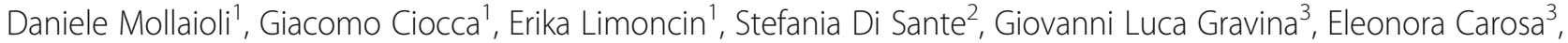 \\ Andrea Lenzi ${ }^{2}$ and Emmanuele Angelo Francesco Jannini ${ }^{*}$
}

\begin{abstract}
Sexual health is strictly related with general health in both genders. In presence of a sexual dysfunction, the expert in sexual medicine aims to discover the specific weight of the physical and psychological factors can cause or con-cause the sexual problem. At the same time, a sexual dysfunction can represent a marker of the future development of a Non-communicable diseases (NCDss) as cardiovascular or metabolic diseases.

In the evaluation phase, the sexual health specialist must focus on these aspects, focusing especially on the risk and protective factors that could impact on both male and female sexuality.

This article presents a review of researches concerning healthy and unhealthy lifestyles and their contribute in the development of sexual quality of life in a gender-dependent manner.

Among the unhealthy lifestyle, obesity contributes mostly to the development of sexual dysfunctions, due to its negative impact on cardiovascular and metabolic function. Tobacco smoking, alcohol - substance abuse and chronic stress lead to the development of sexual dysfunction in a med-long term.

In order to guarantee a satisfying sexual quality of life, sexual health specialists have the responsibility to guide the patient through the adoption of healthy lifestyles, such as avoiding drugs, smoke and excessive alcohol, practicing a regular physical activity, following a balanced diet and use stress-management strategies, even before proposing both pharmaco- and/or psychotherapies.
\end{abstract}

Keywords: Sexual dysfunction, Erectile dysfunction, Coital pain, Loss of libido, Obesity, Mediterranean diet, Chronic stress, Substance use, Alcohol dependence, Physical activity

\section{Introduction}

Sexual health is characterized by a complex and multidimensional process coordinated by neurological, endocrine, and vascular systems [1]. Male and female sexual dysfunctions represent a medical and psychological problem that adversely affect not only physical health and emotional well-being: the impairment of sexual function may have a detrimental effect on self-esteem, body image, interpersonal relationships, and physical health in general, including fertility.

The modifiable risk factors for male and female sexual dysfunctions are: smoking, physical inactivity, obesity and excessive alcohol and drug consumption. Healthy lifestyle changes could be a useful strategy for decreasing

\footnotetext{
* Correspondence: eajannini@gmail.com; emmanuele.jannini@uniroma2.it ${ }^{1}$ Department of Systems Medicine, University of Rome Tor Vergata, Via Montpellier 1, 00133 Rome, Italy

Full list of author information is available at the end of the article
}

the risk of erectile dysfunction (ED) and the other sexual dysfunctions.

Since males and females differ in the expression of sexual behavior and function, both from a biological and psycho-relational point of view, the endpoint of this review is to describe how healthy and unhealthy lifestyles impact differently on male and female sexuality.

The greatest limitation in this field remains the lack of study assessing the impact of lifestyle change on sexual function. On the other hand, however, none of the many therapeutic options available to date offers a complete response in patients with sexual dysfunction, and therefore, as with many other diseases, prevention remains the most effective approach to alleviating the consequences of sexual dysfunction.

(C) The Author(s). 2020 Open Access This article is distributed under the terms of the Creative Commons Attribution 4.0 International License (http://creativecommons.org/licenses/by/4.0/), which permits unrestricted use, distribution, and reproduction in any medium, provided you give appropriate credit to the original author(s) and the source, provide a link to the Creative Commons license, and indicate if changes were made. The Creative Commons Public Domain Dedication waiver (http://creativecommons.org/publicdomain/zero/1.0/) applies to the data made available in this article, unless otherwise stated. 


\section{Obesity}

Obesity is a dramatically serious public health problem and in many countries, it has the characteristics of a real epidemy. Information provided by epidemiological surveillance systems suggests that almost two billion adults are overweight, 500 million of whom are obese, and for the first time, the number of obese individuals in the developed countries is almost equivalent to the number of underweight, with a higher prevalence in men [2].

Together with the high prevalence, obesity negatively impacts on physical, psychic, and sexual health in general. For example, class III obesity has been shown to reduce life expectancy from 6 to 14 years [3]. Another study reveals that the life expectancy reduction in both male and female obese worsen with smoking (from 7.2 to 13.3 years in females, from 6.7 to 13.7 in males) [4].

Obesity, by itself, is an independent risk factor for cardiovascular disease but also increases the incidence of pathologies such as diabetes, dyslipidaemia, hypertension, which, like obesity, are themselves factors of risk for the development of cardiovascular disease [5]. Among psychosocial factors, obesity causes psychological distress, in particular it is a cause of social stigma and weight-related discrimination, adversely affecting the quality of life especially in women [6]. The psychopathology that most weighs on obese people is depression. It has been highlighted that among people extremely obese, the diagnosis of a mood disorder is very common [7].

From a sexual perspective, an American study on sexual dysfunctions in the obese population showed prevalence rates around $7-22 \%$ for women (coital pain, arousal problems, and sexual dissatisfaction) and 5-21\% for men (ED and decrease of desire) [8].

In addition, numerous scientific evidences [9-11] have highlighted the important interconnection between obesity, sexual dysfunction and the development of future Non-Communicable Diseases (NCDs) in general and cardiovascular diseases in particular [1]. At present, the occurrence of sexual dysfunction in obese patients provides an opportunity for the in-depth clinical trials, which in most cases allow them to identify and intervene on an early stage of cardiovascular disease [12]. Unlike men, less is known about the relationship between sexual function and the amount of body fat in the female counterpart. The lack of information is due to the scarcity of the studies and mainly to the different methods used for female sexual evaluation [1].

Patients with ED generally have a body weight and a waist circumference on average higher than healthy patients. In fact, in the Health Professionals Follow-up Study [13], men with a Body Mass Index (BMI) greater than 28.7 had a risk of developing ED more than $30 \%$ of the normal (BMI <25). Similarly, the results of the Massachussets Male Aging Study [14] and Rancho Bernardo
Study [15] studies lasting 9 and 25 years respectively showed that body weight is an independent risk factor for ED with an additional risk 90\% compared to controls (Odd Ratio between 1.93 and 1.96 respectively).

A wider prevalence of ED can also be highlighted in patients with metabolic syndrome that represents a constellation of risk factors for the development of diabetes, coronary heart disease and other vascular complications. For its diagnosis it is necessary to coexist at least three of the criteria coded by the Adult Treatment Panel III: waist circumference $>102 \mathrm{~cm}$ in humans, $>88 \mathrm{~cm}$ in woman; triglycerides $>150 \mathrm{mg} / \mathrm{dl}$; cholesterol-HDL < $40 \mathrm{mg} / \mathrm{dl}$ in humans, $<50 \mathrm{mg} / \mathrm{dl}$ in woman; blood pressure > 130 / 85 mmHg; glycemia $>110 \mathrm{mg} /$ dl) [16].

More and more relevant results suggest that the association between obesity and ED may be explained by endothelial dysfunction [17]. This link has been clinically proven for the first time by Kaiser, comparing men with ED without manifest manifestations or risk factors of vascular disease with a similar control group but without ED. Between the two groups of the study, there were no significant differences in carotid-medial thickness of calcific total-score of the coronary arteries, but there was, however, a significant decrease in vasodilation of the brachial artery in the ED group. These first observations suggested that ED could be considered an extremely early manifestation of vascular insufficiency.

Regarding female sexual health, recent literature data suggest that overweight and obese women have a lower sexual function than healthy women $[18,19]$. It is important to point out how the increase in the severity of obesity is positively correlated with a greater impairment of the sexual quality of life, to a greater extent than that of obese men [20, 21]. In addition, among all obese women, those who report major sexual problems are women who choose bariatric surgery [20-22]. All these results suggest that women with severe obesity, especially those seeking bariatric surgery, represent a population with a high risk of developing sexual dysfunctions.

Only a few studies investigated in a specific way the sexual function in obese women: In a study by Kirchengast et al. [23] found that in postmenopausal women a high BMI was associated with reduced sexual desire. In another study, the prevalence of female sexual dysfunction among women seeking bariatric surgery was higher than in women with infertility (26\%) and women with hypertension (42\%), but similar to those who accessed to the sexological outpatient clinic $(60 \%)$ and lower than women with urogynecological problems (64-68\%) [24].

On the other hand, Esposito et al. [25] discovered a negative relationship between body weight and sexual function in 52 women with abnormal values of FSFI (score $<23$ ), showing that obesity affects several areas of sexual function unlike healthy women with FSD: arousal, 
lubrication, satisfaction, and orgasm, but not desire and pain.

Data from a study based on a sample of obese women preparing for bariatric surgery [26] confirm the Esposito's study results, except for the area of desire, which is significantly lower in the sample of obese women than in the control group. This discrepancy could be attributed to the different impacts that, in the different studied cohorts, may have the relative hyperandrogenism frequently found in female obesity versus the loss of the body image also very common in the same condition $[7,27]$.

Finally, overweight, obesity and a sedentary lifestyle are associated with an increased risk of post-menopausal breast cancer [28, 29], as excessive adiposity increases the concentration of sexual hormones such as estrogen and androgen [30, 31].

\section{Physical activity}

Physical activity is one of the healthiest activities and most of all reduces the risk of chronic diseases (such as diabetes or hypertension) or sexuality [32]. In addition, some studies have shown that an active lifestyle greatly reduces the chance of having an altered blood glucose control. or to improve it if already present [33].

In subjects with sexual dysfunction and suffering from diabetes or severe obesity, physical activity is a very important protective factor: constant physical activity has been a protective effect against ED in men with diabetes [34] as well in women with sexual dysfunction [35].

From a meta-analysis it has been shown that intense and moderate physical activity is associated with a lower risk of developing ED because it increases endothelial NO production and decreases oxidative stress. In addition, exercise has proven beneficial effects on self-esteem and mental health, with a positive impact on psychological problems associated with sexual dysfunction $[14,36]$.

In hypertensive patients with ED, 8-week physical exercise duration of 45 to $60 \mathrm{~min}$ per day improved erectile function compared to controls remaining sedentary during the same period [37]. These data were confirmed by a recent study evaluating the effect of an aerobic physical activity protocol (about $150 \mathrm{~min}$ per week) on the quality of erectile function in middle-aged patients with ED on a vascular basis. After 3 months, patients in the intervention group showed a significant increase in the abridged International Index of Erectile Function (IIEF-5) score associated with a reduction in pro-apoptotic endothelial cells compared to controls [38].

In another study, 60 patients with ED were randomized to receive a type 5 phosphodiesterase inhibitor (PDE5i) alone or in association with regular aerobic activity (about $3 \mathrm{~h}$ a week). After 3 months in the intergroup there was an improvement in the total score of the IIEF of $77.8 \%$ compared to $39.3 \%$ of the control $(p<$ 0.004 ) suggesting that lifestyle changes can significantly increase the benefits of pharmacological therapy for ED. [39]

Similar results were founded in subjects with Premature Ejaculation (PE) [40, 41]. In a recent study, it's been demonstrated that PE symptoms tended to increase with decreasing frequency of physical activity [42]. Being the ejaculatory mechanism itself unrelated to the lifestyle, the unique logical explanation of this effect could be the very frequent comorbidity between ejaculatory and ED [43-45], where one exacerbates the other. Moreover, physical exercises improve self-esteem and body image, which are negatively influenced in subjects with PE [46].

In women, physical exercise can improve many typical symptoms of menopause, particularly mood, sleep, anxiety, depression and musculoskeletal problems [47-49]. Together with these, postmenopausal women who do regular physical activity maintain a good quality of sexual life [48].

In a longitudinal study [50], menopausal women have a better body image when they exercise a constant physical activity, improving their self-esteem, emotion expression, and maintaining an adequate BMI.

Despite the importance of sexuality and physical activity to the quality of life and health of women, studies that evaluate the relationship between these aspects are scarce in the literature.

In a study by Cabral et al., the presence of a sexual dysfunction, measured by the Female Sexual Function Index (FSFI), was found in $67 \%$ of the sample and associated with a sedentary lifestyle. Almost 4 out of 5 women who did not exercise physical activity reported sexual dysfunction (78.9\%) compared to regular physical exercise (57.6\%). Based on these data, the absence of physical activity increases by 2.1 times the chance of having a sexual dysfunction in menopausal women [51].

\section{Loss of weight and dietary factors}

Weight loss, whether through lifestyle changes or through bariatric surgery, is associated with an improvement of many biological, psychological and sexual factors.

Khoo et al. compared the effects of 2-month low calorie diet on insulin sensitivity, plasma testosterone levels, erectile function and sexual desire in obese and diabetic men compared to non-diabetic men but with similar BMI and waist circumference. 10\% weight loss was significantly associated with increased insulin sensitivity, plasma testosterone levels, erectile function and desire in diabetics as well as non-diabetic patients [52]. Similar results were obtained with weight loss induced by bariatric surgery as demonstrated by the increase in the quality of erectile function measured with IIEF-5 and the increase in total testosterone levels [53]. 
The Mediterranean Diet, that includes a high consumption of legumes, vegetables and fruits, and the limited consumption of red meat, dairy products, highadded foods and beverages is associated with a reduction in the risk of ED and other related sexual complaints in both diabetic and non-diabetic patients.

Sixty-five men with metabolic syndrome and ED have been studied; 35 of these were assigned to the diet of intervention according to the Mediterranean diet model and 30 to another diet model. Subjects in the intervention group were invited to consume at least $250-300 \mathrm{~g}$ (g) of fruit, $125-150 \mathrm{~g}$ of vegetables, and $25-50 \mathrm{~g}$ of nuts per day. In addition, they were encouraged to consume $400 \mathrm{~g}$ of whole grain a day (legumes, rice, corn and wheat) and increase the consumption of olive oil. After 2 years, men from the Mediterranean diet group had an increased IIEF score compared to men in the control group [54].

The beneficial effect of the Mediterranean diet on atherosclerosis in general and in particular on ED is mediated by multiple biological pathways, including a reduction in oxidative stress, subclinical inflammation and improved insulin sensitivity, which in turn may increase the release of NO into penile arteries.

Diabetic women who better complied to the Mediterranean diet have reported a lower BMI, a waist circumference and a waist-to-hip ratio, lower levels of depression, obesity and metabolic syndrome, a higher level of physical activity, and better profiles of glucose and lipids compared to women who did not constantly diet. In addition, adherence to the Mediterranean diet has also improved the frequency of sexual intercourse and significantly reduced the prevalence of sexual dysfunction [55].

Moreover, another study reveal that baseline C-reactive protein seem to predict ED in men but no sexual dysfunctions in women [56].

\section{Smoking}

Smoking is a global health problem. A cigarette contains nearly forty thousand chemical compounds, of which 60 are extremely toxic [57]. Epidemiological studies show that smoking contributes to the etiology of many diseases, including respiratory, neurological and oncological circulatory disorders, due to its toxic properties [58].

One of the main effects of cigarette smoking is the decrease in vasodilatation of vascular endothelial tissues: Chronic smoking causes ED in men, while women's role is still controversial [59]. However, it is possible to assume that the complications related to smoking and sexual dysfunction are similar in both sexes.

Both direct use and exposure to tobacco are risk factors for the development of ED. A recent meta-analysis [60] of four prospective cohort studies and four case-control studies involving over 28,000 participants showed that compared to non-smoking, the overall odd ratio of ED in cohort prospective studies was 1.51 (95\% CI: 1.34-1.71) for smokers, and 1.29 (95\% CI: 1.07-1.47) for the exsmokers.

In a prospective study, Pourmand et al. have reported a beneficial effect on erectile function in men who have ceased smoking. After 1 year, the state of ED improves by $25 \%$ in ex-smokers but in none of the current smokers [61].

According to Harte and Meston, the effects of acute nicotine intake diminish $30 \%$ of genital stimulation and cause an alteration of normal sexual response [62]. Battaglia et al. report that the anti-estrogenic effects of smoking negatively impact on uterine, clitoral and labial vascularization [63]. Negative effects are also present in orgasmic function (which is delayed) and in a decrease in vaginal lubrication [63]. Therefore, it is possible to hypothesize that smoking is a risk factor in female sexual function, although the pathophysiological mechanisms of the negative symptoms of smoking on the female sexuality are still unclear.

It is important to emphasize that one of the effects of nicotine is to have a negative impact on sex hormones (androgens and estrogens) [64], and on clitoral blood flow [65]. Therefore, sexual symptoms such as hypo lubrication can be determined by the reduced flow of genital blood. This condition can also lead to a delay in orgasm and a more general decline in sexual relationships and a sense of dissatisfaction for sexual intercourse and couple relationship [10, 64, 65].

Devices proposed in the market to be able to reduce the risk of combusted toxic of cigarette smoking must be carefully evaluated to demonstrate with robust evidences their ability to positively impact on sexual and reproductive health in both genders before to be considered as real advantages and not an alibi to remain in the smoking habit [66].

\section{Alcohol}

Alcohol consumption and sexual behavior are closely linked. Although incorrect, there is a common belief that alcohol is a powerful sexual facilitator, acting as an aphrodisiac and pushing the person towards disinhibited behaviors [67].

Indeed, although low-dose alcohol consumption produces a slight euphoria, leading some people to be more open or receptive to sexual activity, at higher doses alcohol leads to an opposite effect as it tends to attenuate the sexual response in a gender-dependent manner. Indeed, alcohol is a central nervous system depressor that slows down brain function, breathing and blood flow [68]. Consequently, the alcohol consumption, particularly in alcohol-dependent subjects, lead to the development of a sexual dysfunction, especially to ED in men 
and reduced vaginal lubrication in women [68]. Although almost identical in the pathophysiology, erection and lubrication exert, however, a different, genderdependent function in coital activity. The significant reduction in erection may obstacle penetration much more than the same reduction in lubrication. For this reason, alcohol dependence impacts on sexual performance much more in male than in female [69].

Moderate consumption of alcohol can have a protective effect on ED both in the general population and in diabetes [70]. Data from a transverse study based on the assessment of the association between habitual alcohol consumption and ED in Australia revealed that the likelihood of developing ED among drinkers was lower among men who consumed between 1 and 20 standard portions per week [71]. In general, overall results indicate that the consumption of a moderate amount of alcohol per week gives a higher degree of protection [71]. The beneficial effects of alcohol on erectile function may be partly due to the long-term benefits of alcohol on the increase in NO bioavailability. These findings need confirmation in larger populations and with different ages and comorbidities.

There is no doubt that excessive use of alcohol not only has negative effects on life expectancy, but significantly reduces the quality of sexual and relational health through neuro- and vasculo-degenerative mechanisms as well as hormone-toxicity. True alcoholism ultimately has a devastating impact on both social and sexual life [72].

Most of the women who drink large quantities of alcohol report sexual dysfunctions. In a study, female patients seeking treatment for alcohol dependence syndrome reported mostly low sexual desire (55\%), inability to reach orgasm $(52,5 \%)$ and, when reached, unsatisfactory (50\%). Compared with healthy women, alcohol-dependent women reported lower scores in all the sexual domains [73]. Low educational levels, early alcohol initiation, longer alcohol consumption and dependence from other substances seemed to be the most significant predictor of the development of sexual dysfunction [73]. Paradoxically, despite the hypoactive sexual desire disorder, both promiscuity and frequency of (unprotected) sexual activity seem increased both in chronic and acute alcoholic abuse [74].

\section{Substance use}

The psychological and physiological effects that illegal psychoactive substances induce are extremely variable in nature, as they depend not only on the pharmacodynamic aspect of the molecule itself but also on the mode of intake (smoking, orally, intranasally, parenterally), dose, emotional states, expectations related to the substance's intake and the value it has accredited.
Despite the effect of drugs and alcohol on an individual's sexual behaviors [75], sexual dysfunctions have received limited attention in the addiction field [76]. This is particularly strange, considering that the use of illegal drugs is very much related to the attempt to overcome a real of hypothetical sexual dysfunction [77].

Recently, an increasing number of people voluntary intake psychoactive drugs (Gamma-hydroxybutyrate, gamma-butyrolactone, 1,4-butanediol, mephedrone, methamphetamine, ED drugs and alkyl nitrites) in order to enhance sexual performance. This phenomenon, called "ChemSex", is frequent in young people and especially, but not exclusively, in the male homosexual context [78]. At the moment, there are no studies that investigate the prevalence of women addicted to ChemSex.

\section{Marijuana}

Smokers and consumers of Marijuana and its derived, defined Hashish, because of their active agent (delta-9tetrahydrocannabinol, THC) can incur in several risks, above all in cases of chronic abuse. In this regard, many studies investigated the psychological health and the possible exacerbation of psychotic diseases [79]. On the other hand, more controversial is the relationship between marijuana use and sexual functioning. A recent survey by Sun and Eisenberg [80] suggested, with also a certain clamor by traditional and social media, that marijuana consumers have a higher frequency of sexual intercourses compared to non-consumers. However, authors clearly declared the limitations of their study due to self-reported information from participants that limited the direct association between marijuana use and sexual frequency. Another article reports that marijuana and cannabinoids negatively impact and concurs to the physiological decline on testosterone levels in males, while in females marijuana is linked to major facilitatory effects [81].

\section{Cocaine}

Cocaine use induces an increase in fantasies, physical sensitivity during excitement, ability to reach orgasm and sexual satisfaction in both sexes. However, these effects only occur in the early stages of consumption. Long-term cocaine use has a depressive effect on sexual activity [82], also leading to a reduction in the ability to reach orgasm [82]. The use of the substance, sometimes initiated to facilitate sexual stimulation, may cause alterations to the sexual sphere in the long term [83], provoking alterations in the endocrine system and influencing above all the hormonal balance controlling sexual function leading to the loss of sexual desire [83]. They also may produce impotence in man and sexual inactivity in the woman [84]. 
There is also inhibition of ejaculation [85] and a reduction in sexual performance [84].

\section{Amphetamine}

Amphetamine is a stimulant of the sympathetic neurovegetative system. Its short-term use results in an increase in motor activity and sexual desire, a greater sense of power and self-esteem. Some consumers report that the use of amphetamine intensifies orgasm and allows prolonged sexual intercourse [86]. It is a stimulant to the sympathetic neurovegetative system and as such has been considered as a pharmacological aid in those affected by delayed ejaculation [86], a symptom characterized by absence of approved medical therapies [86].

In the long term, however, as all illegal drugs, the sexual symptoms appear, as a decrease in sexual desire, the inhibition of orgasm and, consequently, a reduction of sexual satisfaction [87].

\section{Heroin}

The use of heroin initially proves physical well-being, a feeling of calm and serenity and it increases a feeling of self-confidence. It is often used to diminish the sense of sexual inadequacy, to combat performance anxiety, to improve sexual performance or to control ejaculatory reflex [77]. In women, heroin can be used to reduce the anxiety and pain associated with the relationship as it produces relaxation of the pelvic floor muscles and perhaps an increase in lubrication [77].

The toxic effects associated with prolonged and continuous use of heroin cause a rapid decrease in overall sexual helth. This is because heroin interferes with the central regulation of the endocrine system and therefore alters the functions involved in hormone processes interacting with the endogenous opioid receptors and pathway $[88,89]$.

Heroin-dependent men report several sexual complaints such as loss of libido, ED [90], delayed ejaculation, inability to reach orgasm and infertility [91].

\section{Ecstasy}

In the early stages of assumption, ecstasy can be used in the attempt to overcome the shyness or discomfort associated with a sexual encounter. It gives a sense of mastery of self, of one's own body and of its sexuality [92]. Some research has shown that the substance can lead to an increase in arousal or sensitivity, and in particular to the loss of sexual inhibition [92]. This phenomenon depends on methamphetamine, a powerful neurostimulator that can amplify the feeling of well-being and excitement and maximize sexual experience and orgasm [86]. Long-term ecstasy intake results in a reduction of sexual desire, penile erection, vaginal lubrication, ability to reach orgasm and being sexually satisfied [93].

\section{Chronic stress}

Many people are daily exposed to experiences to small chronic stressors, which are physiological and lead to beneficial effect on health, motivation, performance, and emotional well-being (eustress) [94]. An accumulation of constant, small stressors, as important traumatic events (distress), can potentially contribute to sexual dysfunction [95]. Although stress is generally considered a major contributor of sexual dysfunction, there are only a few studies in the literature that investigate the effect of chronic stress on sexual function and more generally on the quality of life and satisfaction of the couple relationship [96, 97].

Chronic stress is generally defined as "an important life events that induce a prolonged period of stress such as a death in the family" [98] or as "a collection of small stressors that are constantly or frequently present, such as deadlines that never seem to be satisfied, traffic or financial concerns" [99, 100].

From a physiological perspective, an increase in chronic tension induces high levels of cortisol, which can cause harmful effects if it remains altered in the long term. For example, high levels of cortisol cause a reduction in gonadic steroids [101, 102] and adrenal androgens [103-107], which have been shown to have facilitating effects on sexual desire and genital arousal.

From a psychological point of view, stress can alter emotional and cognitive states, preventing the individual from focusing on sexual stimuli during sexual activity. The presence of chronic stress seems therefore to produce harmful effects on sexual desire and genital arousal [104, 108].

It is well known that there is a vicious circle in which sexual dysfunction, chronic stress, anxiety and depression compromise the quality of life of an individual [109]. In this context, it is necessary to accompany pharmacological therapy to the pathways of psychological counseling and psychotherapy [110-112].

In a prospective study of patients with ED, the group benefiting both PDE5i treatment and stress management techniques (diaphragmatic breathing exercises and progressive muscle relaxation) had lower levels of morning cortisol and better scores at IIEF compared to the group of patients who followed only pharmacological therapy. These findings highlighted how high levels of cortisol can inhibit sexual activity and develop sexual symptoms such as ED [113].

In another study, a sample of women with average to high stress levels was recruited and subjected to the viewing of an erotic movie. Women with high stress levels had lower levels of genital, but not psychological arousal, higher levels of cortisol, and reported more distraction during the erotic film than women in the average stress group [114]. Thus, high levels of chronic stress were related to lower levels of genital sexual arousal. Both psychological and hormonal factors were related to the lower levels of sexual arousal seen in women with high chronic stress levels [114]. 


\section{Conclusions}

Sexual health, a crucial and pivotal part of overall health, is a complex interplay of cultural, social, relational, intrapsychic, and biomedical aspects $[115,116]$. In presence of several unhealthy lifestyles, often sexual dysfunction occurs, which mostly represent the precursor of an underlying physical or mental health condition (See Table 1) [117].
The analysis of the literature about the impact of healthy and unhealthy lifestyles on sexuality reported differences in men and women but also similar effects. For example, alcohol abuse seems to produce different negative effects in men and women: reduction of erectile function in the first case, paradox loss of libido and unsatisfactory orgasms in the second one; inversely, physical activity increase sexual function and prevent sexual

Table 1 Risky and protective lifestyles and their effects on male and female sexuality

\begin{tabular}{|c|c|c|}
\hline Factor & Effects on male sexuality & Effects on female sexuality \\
\hline Obesity & $\begin{array}{l}\text { Loss of libido [8] } \\
\text { Risk of } \mathrm{ED}>30 \% \text { with } \mathrm{BMI}>28.7 \text { [13] }\end{array}$ & $\begin{array}{l}\text { Arousal problems, Coital pain and Sexual dissatisfaction [8] } \\
\text { More sexual complaints in women seeking bariatric surgery [22] } \\
\text { Higher risk for postmenopausal breast cancer }[27,28]\end{array}$ \\
\hline Loss of weightand Diet & $\begin{array}{l}\text { 10\% weight loss related with increased insulin } \\
\text { sensitivity, plasma testosterone levels, erectile } \\
\text { function and desire both in diabetics and } \\
\text { non-diabetics [52] } \\
\text { Weight loss induced by bariatric surgery } \\
\text { improve erectile functions and testosterone } \\
\text { levels [53] } \\
\text { Mediterranean diet improves IIEF scores after 2-years [54] }\end{array}$ & $\begin{array}{l}\text { Adherence to Mediterranean diet improve BMI, waist } \\
\text { circumference, waist-to-hip ratio, mood symptoms, weight } \\
\text { and metabolic syndrome [55] } \\
\text { Higher frequency of sexual intercourses in women who better } \\
\text { comply to Mediterranean diet [55] }\end{array}$ \\
\hline Physical Activity & $\begin{array}{l}\text { Protective effects against ED in men with } \\
\text { diabetes [34] } \\
\text { Increase of NO production and decrease } \\
\text { of oxidative stress [14] } \\
\text { Benefits on self-esteem and mental health [36, 41] } \\
\text { Improvement of IIEF-5 score after } 3 \text { months } \\
\text { of physical exercise [38] } \\
\text { Augmented improvement of ED symptoms } \\
\text { in association with PDE5i treatment [39] } \\
\text { Sedentary life increase PE symptoms [41] }\end{array}$ & $\begin{array}{l}\text { Protective effects against sexual dysfunction in women with } \\
\text { diabetes [35] } \\
\text { Benefits on self-esteem and mental health [36, 52] } \\
\text { Improvement of menopause symptoms, mood, anxiety and } \\
\text { musculoskeletal problems [47-49] } \\
\text { Keeping good sexual quality of life in postmenopausal women } \\
\text { who do regular physical activity [48] } \\
\text { Regual physical exercises prevent the development of sexual } \\
\text { dysfunction [51] }\end{array}$ \\
\hline Smoking & $\begin{array}{l}\text { Quit with smoking improve erectile function } \\
\text { by } 25 \% \text { after } 1 \text { year [61] } \\
>50 \% \text { odds to develop ED in smokers and } \\
30 \% \text { in ex-smokers [60] }\end{array}$ & $\begin{array}{l}30 \% \text { decrease of genital stimulation due to nicotine acute } \\
\text { intake }[62] \\
\text { Delayed orgasm and low vaginal lubrication }[10,64,65]\end{array}$ \\
\hline Alcohol abuse & $\begin{array}{l}\text { Lower likelihood of developing ED between } \\
\text { non-habitual drinkers compared to } \\
\text { binge-drinkers }[68,71]\end{array}$ & $\begin{array}{l}\text { Low sexual desire, inability to reach orgasm or unsatisfactory } \\
\text { orgasm in women with an alcohol dependence }[68,73]\end{array}$ \\
\hline Marijuana & $\begin{array}{l}\text { Physiological decline of testosterone } \\
\text { levels [81] }\end{array}$ & It gives major facilitatory effects [81] \\
\hline Cocaine & $\begin{array}{l}\text { Depressive effect on sexual activity and } \\
\text { progressive inability to reach orgasm in } \\
\text { the long term }[82,83] \\
\text { Loss of sexual desire, ED symptoms, } \\
\text { inhibition of ejaculation and reduction in } \\
\text { sexual performance }[83,85]\end{array}$ & Loss of sexual activity [84] \\
\hline Amphetamine & $\begin{array}{l}\text { Decrease in sexual desire, inhibition of orgasm } \\
\text { and a reduction of sexual satisfaction [87] }\end{array}$ & \\
\hline Heroin & $\begin{array}{l}\text { At early stages, it improves sexual inadequacy, } \\
\text { sexual performance and ejaculatory control [88] } \\
\text { Heroin dependence produces loss of } \\
\text { libido and ED [90] } \\
\text { Heroin dependence produces delayed } \\
\text { ejaculation or inability to reach it [91] }\end{array}$ & $\begin{array}{l}\text { At early stages, it reduces anxiety and coital pain, due to } \\
\text { a relaxation of pelvic floor muscles and higher lubrication [88] }\end{array}$ \\
\hline Ecstasy & $\begin{array}{l}\text { At early stages, it reduces sexual inhibition [92] } \\
\text { Long-term use reduces sexual desire and } \\
\text { penile erection [93] }\end{array}$ & $\begin{array}{l}\text { At early stages, it maximized sexual experience and } \\
\text { orgasm [77] } \\
\text { Long-term use reduces vaginal lubrication and ability } \\
\text { to reach satisfying orgasm [93] }\end{array}$ \\
\hline Chronic stress & $\begin{array}{l}\text { PDE5i treatment combined with stress } \\
\text { management techniques reduces cortisol levels } \\
\text { and improves IIEF scores [113] }\end{array}$ & $\begin{array}{l}\text { Chronic stress is related to lower levels of sexual arousal } \\
\text { both in hormonal factors (cortisol) and psychological factors } \\
\text { (attention to visual sexual stimuli) [114] }\end{array}$ \\
\hline
\end{tabular}


dysfunctions in both middle age men and women. A better comprehension of these gender differences should be more deeply studied in future researches.

Independently from the organic or non-organic cause of sexual dysfunction [118], it is important to note that the promotion of correct lifestyles represent the firstline therapeutic option for both sexual physicians and psychosexologists. Changes in lifestyle like alcohol, smoking, and illegal drug cessation, control of diabetes / dyslipidemia, (re)starting physical activity, weight loss and reduction in stress are of prime importance [119].

Finally, in evaluating and treating subjects with sexual dysfunctions, it is important to take care of patients on a systems (previously called biopsychosocial) perspective [1] and recognize that both physical factors (obesity, smoking, alcohol and substance abuse) and psychosocial factors (stress, anxiety, depression, income, culture, experiences, and personality) can not only derive from the sexual dysfunction but they also may contribute to and amplify it. On the other hand, combining efficacious pharmacotherapies with successful additional modalities (such as sexual counselling, sexual education or psychotherapy) to reduce sexual symptoms, is to be regarded as a unique and strong tool in order to motivate the needed, but difficult and hard to perform lifestyle modifications requested to the patient [109].

\section{Acknowledgements}

Not applicable.

\section{Funding}

This review received no specific grant from any funding agency in the public, commercial, or not-for-profit sectors.

\section{Availability of data and materials}

Not applicable.

\section{Authors' contributions}

Drafting the Article: MD; Critical revision: CG, LE, DSS, GGL, CE, LA, JEA; Final approval of the version to be published: JEA. All authors read and approved the final manuscript.

\section{Ethics approval and consent to participate}

Not applicable.

\section{Consent for publication}

Not applicable.

\section{Competing interests}

The authors declare that they have no competing interests.

\section{Author details}

'Department of Systems Medicine, University of Rome Tor Vergata, Via Montpellier 1, 00133 Rome, Italy. ${ }^{2}$ Department of Experimental Medicine, Section of Medical Pathophysiology, Food Science and Endocrinology, Sapienza - University of Rome, Viale Regina Elena 324, Rome 00161, Italy. ${ }^{3}$ Department of Biotechnological and Applied Clinical Sciences, University of L'Aquila, Via Vetoio (Coppito 2), L'Aquila 67100, Italy.
Received: 13 December 2017 Accepted: 17 October 2018

Published online: 17 February 2020

\section{References}

1. Jannini EA. SM = SM: The Interface of Systems Medicine and Sexual Medicine for Facing Non-Communicable Diseases in a Gender-Dependent Manner. Sex Med Rev. 2017:5:349-64.

2. Kanter R, Caballero B. Global gender disparities in obesity: a review. Adv Nutr. 2012;3:491-8.

3. Kitahara CM, Flint AJ, Berrington de Gonzalez A, Bernstein L, Brotzman M, RJ MI, Moore SC, Robien K, Rosenberg PS, Singh PN, Weiderpass E, Adami HO, Anton-Culver H, Ballard-Barbash R, Buring JE, Freedman DM, Fraser GE, Beane Freeman LE, Gapstur SM, Gaziano JM, Giles GG, Håkansson N, Hoppin JA, Hu FB, Koenig K, Linet MS, Park Y, Patel AV, Purdue MP, Schairer C, Sesso HD, Visvanathan K, White E, Wolk A, Zeleniuch-Jacquotte A, Hartge P. Association between Class III Obesity (BMI of $40-59 \mathrm{~kg} / \mathrm{m}$ ) and Mortality: A Pooled Analysis of 20 Prospective Studies. PLoS Med. 2014;11(7):e1001673.

4. Peeters A, Barendregt JJ, Willekens F, Mackenbach JP, Al Mamun A, Bonneux L, NEDCOM, the Netherlands epidemiology and demography compression of morbidity research group. NEDCOM, the Netherlands epidemiology and demographic compression on morbidity research group. obesity in adulthood and its consequences for life expectancy: a life-table analysis. Ann Intern Med. 2003;138:24-32.

5. Kopelman PG. Obesity as a medical problem. Nature. 2000;404:635-43.

6. Bajos N, Wellings K, Laborder C, Moreau C. Sexuality and obesity, a gender perspective: results from French national random probability survey of sexual behaviours. BMJ. 2010;340:C2573.

7. Luppino FS, de Wit LM, Bouvy PF, Stijnen T, Cuijpers P, Penninx BW, Zitman FG. Overweight, obesity, and depression: a systematic review and metaanalysis of longitudinal studies. Arch Gen Psychiatry. 2010;67:220-9.

8. Limoncin E, Ciocca G, Mollaioli D, Jannini EA. Sexual distress in obesity. In: Lenzi A, Migliaccio S, Donini L, editors. Multidisciplinary approach to obesity. Cham: Springer International Publishing; 2015. p. 145-53.

9. Banks E, Joshy G, Abhayaratna WP, Kritharides L, Macdonald PS, Korda RJ, Chalmers JP. Erectile dysfunction severity as a risk marker for cardiovascular disease hospitalization and all-cause mortality: a prospective cohort study. PLoS Med. 2013;10:e1001372

10. Miner M, Esposito K, Guay A, Montorsi P, Goldstein I. Cardiometabolic risk and female sexual health: the Princeton III summary. J Sex Med. 2012;9:641-51.

11. Maiorino Ml, Bellastella G, Castaldo F, et al. Sexual function in young women with type 1 diabetes: the METRO study. J Endocrinol Investig. 2017; 40:169-77.

12. Inman BA, Sauver JL, Jacobson DJ, McGree ME, Nehra A, Lieber MM, Roger $V L$, Jacobsen SJ. A population-based, longitudinal study of erectile dysfunction and future coronary artery disease. Mayo Clin Proc. 2009;84: 108-13.

13. Bacon CG, Mittleman MA, Kawachi I, Giovannucci E, Glasser DB, Rimm EB. Sexual function in men older than 50 years of age: results from the health professionals follow-up study. Ann Intern Med. 2003;139:161-8.

14. Feldman HA, Johannes CB, Derby CA, Kleinman KP, Mohr BA, Araujo AB, McKinlay JB. Erectile dysfunction and coronary risk factors: prospective results from the Massachusetts male aging study. Prev Med. 2000;30:328-38.

15. Fung MM, Bettencourt $R$, Barrett-Connor $H$. Heart disease risk factors predict erectile dysfunction 25 years later. J Am Coll Cardiol. 2004;43:1405-11.

16. Expert Panel on Detection, Evaluation, and Treatment of High Blood Cholesterol in Adults. Executive Summary of The Third Report of The National Cholesterol Education Program (NCEP) Expert Panel on Detection, Evaluation, And Treatment of High Blood Cholesterol In Adults (Adult Treatment Panel III). JAMA. 2001;285:2486-97.

17. Solomon H, Man JW, Jackson G. Erectile dysfunction and the cardiovascular patient: endothelial dysfunction is the common denominator. Heart. 2003; 89:251-3.

18. Esposito K, Ciotola M, Giugliano F, Bisogni C, Schisano B, Autorino R, Cobellis L, De Sio M, Colacurci N, Giugliano D. Association of body weight with sexual function in women. Int J Impot Res. 2007;19:353-7.

19. Melin I, Falconer C, Rössner S, Altman D. Sexual dysfunction in obese women: impact of lower urinary tract dysfunction. Int J Obes. 2008;32:1312-8.

20. Kolotkin RL, Binks M, Crosby RD, Østbye T, Gress RE, Adams TD. Obesity and sexual quality of life. Obesity. 2006;14:472-9. 
21. Kolotkin RL, Crosby RD, Gress RE, Hunt SC, Engel SG, Adams TD. Health and health-related quality of life: differences between men and women who seek gastric bypass surgery. Surg Obes Relat Dis. 2008;4:651-9.

22. Kolotkin RL, Crosby RD, Pendelton R, Strong M, Gress R, Adams T. Healthrelated quality of life in patients seeking gastric bypass surgery vs nontreatment seeking controls. Obes Surg. 2003;13:371-7.

23. Kirchengast S, Hartmann B, Gruber D, Huber J. Decreased sexual interest and its relationship to body build in postmenopausal women. Maturitas. 1996;23:63-71.

24. Bond DS, Vithiananthan S, Leahey TM, Thomas JG, Sax HC, Pohl D, Ryder BA Roye GD, Giovanni J, Wing RR. Prevalence and degree of sexual dysfunction in a sample of women seeking bariatric surgery. Surg Obes Relat Dis. 2009;5: 698-704.

25. Esposito K, Ciotola M, Marfella R, Di Tommaso D, Cobellis L, Giugliano D. The metabolic syndrome: a cause of sexual dysfunction in women. Int J Impot Res. 2005;17:224-6.

26. Assimakopoulos K, Panayiotopoulos S, Iconomou G, Karaivazoglou K Matzaroglou C, Vagenas K, Kalfarentzos F. Assessing sexual function in obese women preparing for bariatric surgery. Obes Surg. 2006;16:1087-91.

27. Liao LM, Nesic J, Chadwick PM, Brooke-Wavell K, Prelevic GM. Exercise and body image distress in overweight and obese women with polycystic ovary syndrome: a pilot investigation. Gynecol Endocrinol. 2008;24:555-61.

28. Renehan AG, Tyson M, Egger M, Heller RF, Zwahlen M. Body-mass index and incidence of cancer: a systematic review and meta-analysis of prospective observational studies. Lancet. 2008;371:569-78.

29. Endogenous Hormones and Breast Cancer Collaborative Group, et al. Circulating sex hormones and breast cancer risk factors in postmenopausal women: Reanalysis of 13 studies. Br J Cancer. 2011;105:709-2 2.

30. Woolcott CG, Shvetsov YB, Stanczyk FZ, Wilkens LR, White KK, Caberto C, Henderson BE, Le Marchand L, Kolonel LN, Goodman MT. Plasma sex hormone concentrations and breast cancer risk in an ethnically diverse population of postmenopausal women: the multiethnic cohort study. Endocr Relat Cancer. 2010;17:125-34.

31. Sieri S, Krogh V, Bolelli G, Abagnato CA, Grioni S, Pala V, Evangelista A, Allemani C, Micheli A, Tagliabue G, Schunemann HJ, Menard S, Berrino F, Muti P. Sex hormone levels, breast cancer risk, and cancer receptor status in postmenopausal women: the ORDET cohort. Cancer Epidemiol Biomark Prev. 2009:18:169-76.

32. Helmrich SP, Ragland DR, Leung RW, Paffenbarger RS Jr. Physical activity and reduced occurrence of non-insulin-dependent diabetes mellitus. N Engl J Med. 1991;325:147-52.

33. Knowler WC, Barrett-Connor E, Fowler SE, Hamman RF, Lachin JM, Walker EA, Nathan DM, Diabetes Prevention Program Research Group. Reduction in the incidence of type 2 diabetes with lifestyle intervention or metformin. N Engl J Med. 2002:346:393-403.

34. Kalter-Leibovici O, Wainstein J, Ziv A, Harman-Bohem I, Murad H, Raz I, Israel Diabetes Research Group (IDRG) Investigators. Clinical socioeconomic, and lifestyle parameters associated with erectile dysfunction among diabetic men. Diabetes Care. 2005;28:1739-44.

35. Esposito K, Maiorino MI, Bellastella G, Giugliano F, Romano M, Giugliano D. Determinants of female sexual dysfunction in type 2 diabetes. Int J Impot Res. 2010;22:179-84.

36. Bacon CG, Mittleman MA, Kawachi I, Giovannucci E, Glasser DB, Rimm EB. A prospective study of risk factors for erectile dysfunction. J Urol. 2006;176:217-21.

37. Lamina S, Okoye CG, Dagogo TT. Therapeutic effect of an interval exercise training program in the management of erectile dysfunction in hypertensive patients. J Clin Hypertens (Greenwich). 2009;11:125-9.

38. La Vignera S, Condorelli R, Vicari E, D'Agata R, Calogero A. Aerobic physical activity improves endothelial function in the middle-aged patients with erectile dysfunction. Aging Male. 2011;14:265-72.

39. Maio G, Saraeb S, Marchiori A. Physical activity and PDE5 inhibitors in the treatment of erectile dysfunction: results of a randomized controlled study. J Sex Med. 2010;7:2201-8.

40. Ventus D, Jern P. Lifestyle factors and premature ejaculation: are physical exercise, alcohol consumption, and body mass index associated with premature ejaculation and comorbid erectile problems? J Sex Med. 2016;13:1482-7.

41. McMahon CG, Jannini EA, Serefoglu EC, Hellstrom WJ. The pathophysiology of acquired premature ejaculation. Transl Androl Urol. 2016;5:434-49.

42. Jannini EA, Ciocca G, Limoncin E, Mollaioli D, Di Sante S, Gianfrilli D, Lombardo F, Lenzi A. Premature ejaculation: old story, new insights. Fertil Steril. 2015;104:1061-73.
43. Corona G, Rastrelli G, Limoncin E, Sforza A, Jannini EA, Maggi M. Interplay between premature ejaculation and erectile dysfunction: a systematic review and meta-analysis. J Sex Med. 2015;12:2291-300.

44. Jannini EA, McMahon C, Chen J, Aversa A, Perelman M. The controversial role of phosphodiesterase type 5 inhibitors in the treatment of premature ejaculation. J Sex Med. 2011:8(8):2135-43.

45. Jannini EA, Lombardo F, Lenzi A. Correlation between ejaculatory and erectile dysfunction. Int J Androl. 2005;28:40-5.

46. Limoncin E, Lotti F, Rossi M, Maseroli E, Gravina GL, Ciocca G, Mollaioli D, Di Sante S, Maggi M, Lenzi A, Jannini EA. The impact of premature ejaculation on the subjective perception of orgasmic intensity: validation and standardization of the 'Orgasmometer'. Andrology. 2016;4:921-6.

47. Skrzypulec $V$, Dabrowska J, Drosdzol A. The in uence of physical activity level on climacteric symptoms in menopausal women. Climacteric. 2010;13: 355-61.

48. Li S, Holm K, Gulanick M, Lanuza D, Penckofer S. The relationship between physical activity and perimenopause. Health Care Women Int. 1999;20:163-78.

49. Llaneza P, Fernández-I narrea JM, Arnott B, García-Portilla MP, Chedraui P, Pérez-López FR. Sexual function assessment in postmenopausal women with the 14-item changes in sexual functioning questionnaire. J Sex Med 2011; 8: 2144-2151.

50. Elavsky S, McAuley E, Moti RW, Konopack JF, Marquez DX, Hu L. Longitudinal examination of the exercise and self-esteem model in middleaged women. J Sport Exerc Psychol. 2010;32:862-80.

51. Cabral PU, Canário AC, Spyrides MH, Uchôa SA, Eleutério Júnior J, Giraldo PC, Gonçalves AK. Physical activity and sexual function in middle-aged women. Rev Assoc Med Bras. 2014;60:47-52.

52. Khoo J, Piantadosi C, Worthley S, Wittert GA. Effects of a low-energy diet on sexual function and lower urinary tract symptoms in obese men. Int J Obes. 2010:34:1396-403.

53. Corona G, Rastrelli G, Monami M, Saad F, Luconi M, Lucchese M, Facchiano E, Sforza A, Forti G, Mannucci E, Maggi M. Body weight loss reverts obesityassociated hypogonadotropic hypogonadism: a systematic review and meta-analysis. Eur J Endocrinol. 2013;168:829-43.

54. Esposito K, Ciotola M, Giugliano F, De Sio M, Giugliano G, D'armiento M, Giugliano D. Mediterranean diet improves erectile function in subjects with the metabolic syndrome. Int J Impot Res. 2006;18:405-10.

55. Giugliano F, Maiorino MI, Di Palo C, Autorino R, De Sio M, Giugliano D, Esposito K. Adherence to Mediterranean diet and sexual function in women with type 2 diabetes. J Sex Med. 2010;7:1883-90.

56. Maiorino MI, Bellastella G, Caputo M, Castaldo F, Improta MR, Giugliano D, Esposito K. Effects of Mediterranean diet on sexual function in people with newly diagnosed type 2 diabetes: the MÈDITA trial. J Diabetes Complicat. 2016;30:1519-24.

57. Shiverick KT, Salafia C. Cigarette smoking and pregnancy I: ovarian, uterine and placental effects. Placenta. 1999;20:265-72.

58. Institute of Medicine. Women's health research: Progress, pitfalls, and promise. Washington DC: National Academies Press; 2010.

59. Kovac JR, Labbate C, Ramasamy R, Tang D, Lipshultz LI. Effects of cigarette smoking on erectile dysfunction. Andrologia. 2015;47:1087-92.

60. Cao S, Yin X, Wang Y, Zhou H, Song F, Lu Z. Smoking and risk of erectile dysfunction: systematic review of observational studies with meta-analysis. PLoS One. 2013:8:e60443.

61. Pourmand G, Alidaee MR, Rasuli S, Maleki A, Mehrsai A. Do cigarette smokers with erectile dysfunction benefit from stopping? A prospective study. BJU Int. 2004;94:1310-3.

62. Harte $C B$, Meston $C M$. The inhibitory effects of nicotine on physiological sexual arousal in nonsmoking women: results from a randomized, doubleblind, placebo-controlled, cross-over trial. J Sex Med. 2008;5:1184-97.

63. Battaglia C, Venturoli S. Persistent genital arousal disorder and trazodone. Morphometric and vascular modi cations of the clitoris. A case report. J Sex Med. 2009:6:2896-900.

64. Park MG, Ko KW, Oh MM, Bae JH, Kim JJ, Moon du G. Effects of smoking on plasma testosterone level and erectile function in rats. J Sex Med 2012; 9: 472-481.

65. McCall-Hosenfeld JS, Freund KM, Legault C, Jaramillo SA, Cochrane BB, Manson JE, Wenger NK, Eaton CB, McNeeley SG, Rodriguez BL, Bonds D. Sexual satisfaction and cardiovascular disease: the Women's health initiative. Am J Med. 2008;121:295-301.

66. England LJ, Anderson BL, Tong VT, Mahoney J, Coleman-Cowger VH, Melstrom P, Schulkin J. Screening practices and attitudes of obstetricians- 
gynecologists toward new and emerging tobacco products. Am J Obstet Gynecol. 2014;211:695 e1-7.

67. Rosen RC. Alcohol and drug effects on sexual response: human experimental and clinical studies. Ann Rev Sex Res. 1991;2:119-79.

68. Peugh J, Belenko S. Alcohol, drugs, and sexual function: a review. J Psychoactive Drugs. 2001;33:223-32

69. Erol A, Karpyak VM. Sex and gender-related differences in alcohol use and its consequences: contemporary knowledge and future research considerations. Drug Alcohol Depend. 2015;156:1-13.

70. Meldrum DR, Gambone JC, Morris MA, Ignarro LJ. A multifaceted approach to maximize erectile function and vascular health. Fertil Steril. 2010;94:2514-20.

71. Chew KK, Bremner A, Stuckey B, Earle C, Jamrozik K. Alcohol consumption and male erectile dysfunction: an unfounded reputation for risk? J Sex Med. 2009;6:1386-94.

72. Moss HB. The impact of alcohol on society: a brief overview. Soc Work Public Health. 2013;28:175-7.

73. Bn AK, M S, J SR, Dr P. sexual dysfunction in women with alcohol dependence syndrome: a study from India. Asian J Psychiatr 2017; 28: 9-14.

74. Simons JS, Simons RM, Maisto SA, Hahn AM, Walters KJ. Daily associations between alcohol and sexual behavior in young adults. Exp Clin Psychopharmacol. 2018:26:36-48.

75. Cohen S, Kühn KU, Sträter B, Scherbaum N, Weig W. Adverse side-effect on sexual function caused by psychotropic drugs and psychotropic substances. Nervenarzt. 2010;81:1129-37.

76. Harvey DB. Sexual health in drug and alcohol treatment: group facilitator's manual. New York: Springer; 2009.

77. La Pera G, Carderi A, Marianantoni Z, Peris F, Lentini M, Taggi F. Sexual dysfunction prior to first drug use among former drug addicts and its possible causal meaning on drug addiction: preliminary results. J Sex Med. 2008;:5:164-72

78. Giorgetti R, Tagliabracci A, Schifano F, Zaami S, Marinelli E, Busardò FP. When "Chems" meet sex: a rising phenomenon called "ChemSex". Curr Neuropharmacol. 2017;15:762-70

79. Murray RM, Bhavsar V, Tripoli G, Howes O. 30 years on: how the neurodevelopmental hypothesis of schizophrenia morphed into the developmental risk factor model of psychosis. Schizophr Bull. 2017;43: 1190-6.

80. Sun AJ, Eisenberg ML. Association between marijuana use and sexual frequency in the United States: a population-based study. J Sex Med. 2017; 14:1342-7.

81. Gorzalka BB, Hill MN, Chang SCH. Male-female differences in the effects of cannabinoids on sexual behavior and gonadal hormone function. Horm Behav. 2010;58:91-9.

82. Zaazaa A, Bella AJ, Shamloul R. Drug addiction and sexual dysfunction. Endocrinol Metab Clin N Am. 2013:42:585-92.

83. Mello NK. Hormones, nicotine and cocaine: clinical studies. Horm Behav. 2010:58:57-71.

84. Johnson SD, Phelps DL, Cottler LB. The association of sexual dysfunction and substance use among a community epidemiological sample. Arch Sex Behav. 2004;33:55-63.

85. Di Sante S, Mollaioli D, Gravina GL, Ciocca G, Limoncin E, Carosa E, Lenzi A, Jannini EA. Epidemiology of delayed ejaculation. Transl Androl Urol. 2016;5: 541-8.

86. Skårner A, Svensson B. Amphetamine use and sexual practices. Nordic Stud Alcohol Drugs. 2013:30:403-23.

87. Chou NH, Huang YJ, Jiann BP. The impact of illicit use of amphetamine on male sexual functions. J Sex Med. 2015;12:1694-702.

88. Fabbri A, Jannini EA, Gnessi L, Moretti C, Ulisse S, Franzese A, Lazzari R, Fraioli F, Frajese G, Isidori A. Endorphins in male impotence: evidence for naltrexone stimulation of erectile activity in patient therapy. Psychoneuroendocrinology. 1989;14:103-11.

89. Fabbri A, Jannini EA, Gnessi L, Ulisse S, Moretti C, Isidori A. Neuroendocrine control of male reproductive function. The opioid system as a model of control at multiple sites. J Steroid Biochem. 1989:32:145-50

90. Quaglio G, Lugoboni F, Pattaro C, Melara B, Mezzelani P, Des Jarlais DC. Erectile dysfunction in male heroin users, receiving methadone and buprenorphine maintenance treatment. Drug Alcohol Depend. 2008;94 $12-8$

91. Chekuri V, Gerber D, Brodie A, Krishnadas R. Premature ejaculation and other sexual dysfunctions in opiate dependent men receiving methadone substitution treatment. Addict Behav. 2012;37:124-6.
92. Sumnall HR, Cole JC, Jerome L. The varieties of ecstatic experience: an exploration of the subjective experiences of ecstasy. Psychopharmacol. 2006;20:670-82.

93. Zemishlany Z, Aizenberg D, Weizman A. Subjective effects of MDMA ('Ecstasy') on human sexual function. Eur Psychiatry. 2001;16:127-30.

94. Perciavalle V, Blandini M, Fecarotta P, Buscemi A, Di Corrado D, Bertolo L, Fichera F, Coco M. The role of deep breathing on stress. Neurol Sci. 2017;38:451-8.

95. Ciocca G, Carosa E, Stornelli M, Limoncin E, Gravina GL, lannarelli R, Sperandio A, Di Sante S, Lenzi A, Lauro D, Jannini EA. Post-traumatic stress disorder, coping strategies and type 2 diabetes: psychometric assessment after L'Aquila earthquake. Acta Diabetol. 2015;52:513-21.

96. Bancroft J, Loftus J, Long JS. Distress about sex: a national survey of women in heterosexual relationships. Arch Sex Behav. 2003:32:193-209.

97. Kingsberg SA, Janata JW. Female sexual disorders: assessment, diagnosis, and treatment. Urol Clin N Am. 2007:34:497-506.

98. Sarason IG, Johnson JH, Siegel JM. Assessing the impact of life changes: development of the life experiences survey. J Consult Clin Psychol. 1978;46: 932-46

99. Kanner AD, Coyne JC, Schaefer C, Lazarus RS. Comparison of two modes of stress measurement: daily hassles and uplifts versus major life events. J Behav Med. 1981:4:1-39.

100. Lazarus R. Puzzles in the study of daily hassles. J Behav Med. 1984;7:375-89.

101. Breen KM, Karsch FJ. Does cortisol inhibit pulsatile luteinizing hormone secretion at the hypothalamic or pituitary level? Endocrinology. 2004;145: 692-8.

102. Gore AC, Attardi B, DeFranco DB. Glucocorticoid repression of the reproductive axis: effects on $\mathrm{GnRH}$ and gonadotropin subunit mRNA levels. Mol Cell Endocrinol. 2006;256:40-8.

103. Guay A, Jacobson J, Munarriz R, Traish A, Talakoub L, Quirk F, Goldstein I, Spark R. Serum androgen levels in healthy premenopausal women with and without sexual dysfunction: part B: reduced serum androgen levels in healthy premenopausal women with complaints of sexual dysfunction. Int J Impot Res. 2004;16:121-9.

104. Salemink E, van Lankveld J. The effects of increasing neutral distraction on sexual responding of women with and without sexual problems. Arch Sex Behav. 2006:35:175-86

105. Lennartsson A-K, Kushnir MM, Bergquist J, Jonsdottir IH. DHEA and DHEA-S response to acute psychosocial stress in healthy men and women. Biol Psychol. 2012;90:143-9.

106. Izawa S, Saito K, Shirotsuki K, Sugaya N, Nomura S. Effects of prolonged stress on salivary cortisol and dehydroepiandrosterone: a study of a twoweek teaching practice. Psychoneuroendocrinology. 2012;37:852-8.

107. Jeckel CM, Lopes RP, Berleze MC, Luz C, Feix L, Argimon II, Stein LM, Bauer ME. Neuroendocrine and immunological correlates of chronic stress in "strictly healthy" populations. Neuroimmunomodulation. 2010;17:9-18.

108. Barlow DH. Causes of sexual dysfunction: the role of anxiety and cognitive interference. J Consult Clin Psychol. 1986:54:140-8.

109. Ciocca G, Limoncin E, Mollaioli D, Gravina GL, Di Sante S, Carosa E, Lenzi A, Jannini EA. Integrating psychotherapy and pharmacotherapy in the treatment of premature ejaculation. Arab J Urol. 2013;11:305-12.

110. Jannini EA, Lenzi $A$, Wagner $G$. Behavioural therapy and counselling. In: Schill WB, Comhaire F, Hargreave TB, editors. Andrology for the clinician. London: Springer; 2006. p. 598-607.

111. Perelman MA. Psychosocial evaluation and combination treatment of men with erectile dysfunction. Urol Clin North Am. 2005:32:431-45.

112. Hedon F. Anxiety and erectile dysfunction: a global approach to ED enhances results and quality of life. Int J Impot Res. 2003;15:S16-9.

113. Kalaitzidou I, Venetikou MS, Konstadinidis K, Artemiadis AK, Chrousos G, Darviri C. Stress management and erectile dysfunction: a pilot comparative study. Andrologia. 2014;46:698-702.

114. Hamilton LD, Meston CM. Chronic stress and sexual function in women. J Sex Med. 2013:10:2443-54.

115. Report of a technical consultation on sexual health, 28-31 January 2002. Geneva: World Health Organization; 2006. [28 January 2015]. Defining sexual health. http:/ www.who.int/reproductivehealth/publications/sexual_health/defining_sh/en.

116. Jannini EA, Limoncin E, Ciocca G, Buehler S, Krychman M. Ethical aspects of sexual medicine. Internet, vibrators, and other sex aids: toys or therapeutic instruments? J Sex Med. 2012:9:2994-3001.

117. Jannini EA, Isidori AM, Aversa A, Lenzi A, Althof SE. Which is first? The controversial issue of precedence in the treatment of male sexual dysfunctions. J Sex Med. 2013;10:2359-69. 
118. Jannini EA, McCabe MP, Salonia A, Montorsi F, Sachs BD. Organic vs. psychogenic? The Manichean diagnosis in sexual medicine. J Sex Med. 2010;7:1726-33.

119. Corona G, Ricca V, Bandini E, Rastrelli G, Casale H, Jannini EA, Sforza A, Forti G, Mannucci E, Maggi M. SIEDY scale 3, a new instrument to detect psychological component in subjects with erectile dysfunction. J Sex Med. 2012;9:2017-26

\section{Publisher's Note}

Springer Nature remains neutral with regard to jurisdictional claims in published maps and institutional affiliations.

Ready to submit your research? Choose BMC and benefit from:

- fast, convenient online submission

- thorough peer review by experienced researchers in your field

- rapid publication on acceptance

- support for research data, including large and complex data types

- gold Open Access which fosters wider collaboration and increased citations

- maximum visibility for your research: over $100 \mathrm{M}$ website views per year

At BMC, research is always in progress.

Learn more biomedcentral.com/submissions 